Northern Review

yukoncollege.yk.ca/review

\title{
Understanding the Social and Economic Impacts of Mining Development in Inuit Communities: Experiences with Past and Present Mines in Inuit Nunangat
}

\author{
Thierry Rodon and Francis Lévesque
}

\begin{abstract}
In this article, we examine whether the social and economic impacts of mines on Inuit communities have changed over time, based on Inuit experiences. After an overview of the past experiences of Inuit with the mining industry in Inuit Nunangat between 1957 and the early 2000s, we analyze the complex relation between Inuit communities in the vicinity of mines using recent fieldwork conducted in the Inuit communities located near two active mines in Inuit Nunangat: Salluit and Kangiqsujuaq (Nunavik) and the Raglan nickel mine and Qamani'tuaq (Baker Lake, Nunavut) and the Meadowbank gold mine. We argue that much work remains to be done to understand the economic and social impacts of mining development on Inuit communities.
\end{abstract}

\section{Introduction}

Arctic Canada's mining potential has long been known. In the mid-twentieth century, mineral exploration was already underway throughout Inuit Nunangat (Inuit territory) (Boutet 2010; Keeling \& Sandlos 2009; Sandlos \& Keeling 2012; Rodon et al. 2013). At that time, the relationship between mining development and the Inuit was already very closely linked to policies introduced by the Liberal government of Louis St-Laurent (1948-1957) and the Progressive Conservative government of John Diefenbaker (1957-1963). Indeed, the first exploration and exploitation projects were being carried out while the federal government was imposing the welfare state across the whole Arctic and thus depriving Inuit of some control over their lives

The Northern Review 41 (2015): 13-39 
(Zaslow 1988). During this period, Ottawa's goal was to develop the North and "civilize" Inuit by giving them the same advantages and opportunities as their fellow citizens in the South (Lesage 1955; Robertson 1960). The opening of mines was seen as a great opportunity to do both and was therefore encouraged by the Canadian government.

For example, from 1957 to 1962, a mine extracted copper and nickel at Rankin Inlet (Cater \& Keeling 2013). On northern Baffin Island, the Nanisivik mine operated from 1976 to 2002 (Lim 2013; Tester et. al 2013). Between 1982 and 2002, the Polaris mine operated on Little Cornwallis Island (Green 2013), near Resolute Bay. Nunavik, too, had a long experience with the mining industry that featured a period of intensive exploration from the 1950s onward, which left behind many scars on the territory (Duhaime et al. 2005). This exploration led to mining of an asbestos deposit at the Asbestos Hill mine between 1972 and 1980 .

Since then, the juridical/legal and institutional contexts have greatly evolved. Unlike the days when resource development was planned as if the territory was "terra nullius," Nunavik (James Bay and Northern Quebec Agreement) and Nunavut (Nunavut Land Claims Agreement) are now covered by land claims settlements that have led to specific environmental regimes which, above all, have put into place regional administrations and governments, thus increasing Inuit participation in decision making (Rodon 2010; White 2009). The mining industry is also subject to increasingly elaborate environmental assessment processes. To gain social licence to operate (Prno \& Slocombe 2012), and to avoid lengthy litigation processes, mining companies have developed the practice of signing Impact and Benefit Agreements (IBA) with Aboriginal organizations that represent communities affected by development. These agreements offer financial compensation, profit sharing, training programs, scholarships, and so on (Knotsch et al. 2010).

Inuit communities from Nunavik and Nunavut thus now seem to be in a better position to get more benefits out of mining development than they were half a century ago. But are they? Two opposing arguments are invoked to answer this question.

For advocates of economic modernization, natural resource development helps improve the conditions of life in resource-rich regions. This narrative has dominated Canadian political discourse for more than half a century (Page 1986; Canadian Press 2011; Galloway 2011; Rea 1968). Both Québec City and Ottawa have encouraged mining and other resource development projects in the Arctic under the assumption that these projects would participate in the economic and social development of the territory and benefit local Inuit 
populations. Whereas past mine developments were initiated and supported by governments financially and with built infrastructure, the strategy has shifted and they are now encouraged to secure private investment, albeit with tax incentives and infrastructure funding through initiatives like the Plan Nord and CanNor (Canadian Northern Economic Development Agency).

Others, however, have argued that, besides having economic effects that are hard to quantify (Haley et al. 2011), mine development has contributed little to improving the conditions of life of Arctic communities (Abele 2009). In fact, some have shown that regions that are rich in natural resources are often those that suffer from underdevelopment (Sachs \& Warner 2001). Furthermore, Arctic communities cannot always make the most of the economic benefits (Duhaime et al. 2011), in large part because they are seldom consulted (Asselin 2011), while they have to bear the brunt of major social impacts with little capacity to mitigate these impacts (Keller 2012; Rodon et al. 2014). In addition, communities lose the mainstay of their economies when mines close (Lim 2013).

In this article, using the Inuit experience provided by research reports and interviews conducted in Inuit communities, we provide a portrait of the complex relation between mines and Inuit communities in order to highlight the Inuit perception of their social and economic impacts over time. To do so, we first review the available information on mining development between 1957 and the 1990s in Inuit Nunangat using academic literature, oral accounts, and the few available environmental and social follow-up studies that exist. Then, we compare two contemporary mining projects that have been in operation for several years - Raglan in Nunavik and Meadowbank in Nunavut-using findings from our own fieldwork, research reports, and academic publications. This will allow us to point to whether the Inuit perceptions of the socio-economic impacts of mines have changed over time, thus reflecting, or not, the increased power that Inuit have gained through land claims settlement, and the change in the regulatory framework of mining in the North.

\section{History of Mining in the Canadian Arctic: 1957-1990s}

The first modern mine to operate in Inuit Nunangat opened in 1957; the Rankin Inlet mine employed eighty Inuit full-time and around twenty others part-time in 1961 (McPherson 2003: 7-12). To recruit its employees, the mine had worked closely with the then Department of Indian Affairs, which covered the costs of transporting workers to the mine site (Williamson 1974: 
111). Peter Ittinuar, whose father Ollie (1921-2013) was a miner at Rankin Inlet, reminisced about this experience in generally positive terms:

... my father, along with many families from Chesterfield Inlet, decided to move to Rankin Inlet because the money to be made in the mine was unheard of. ... The mine had a very forward-looking manager; Andy Easton was his name. His name is still revered by people in Rankin Inlet. He hired any Inuk who would come in as often as he could, mostly for labour jobs, but also he hired them as carpenters, heavy equipment operators, elevator operators in the shaft, and as mucking machine operators. He hired them to work in the mill. There was a lot of employment for Inuit at the time. (Itinuar 2008: 33-34)

The mine caused many changes in the community. For example, the children who grew up there learned English even before they went to school (Ittinuar 2008:36-37). The mine also raised the incomes of many Inuit families who began to wear European clothing and acquire goods such as washing machines, boats, and several rifles (McPherson 2003). The mine planned social activities, dances, and also parties for adults. According to Ittinuar: "In those days there never seemed to be violence, just giggling people, but now it's different" (Ittinuar 2008: 37).

Community life was structured around three focal points: the ethnic groups, the mine, and the church (Ittinuar 2008: 36). Rankin Inlet was a diverse community with outside workers and Inuit from other areas: according to the Department of Northern Affairs (DNA), 65\% of Inuit employees came from Chesterfield Inlet, 25\% from Arviat, and the others from Repulse Bay and Baker Lake (McPherson 2003: 8). Many Inuit families were also relocated to Rankin Inlet during the Keewatin Re-Establishment Project, DNA's response to the famine experienced by many interior Inuit in 1957-1958 (Tester and Kulchyski 1994: 274-305). Peter Ittinuar (2008: 38) says the diversity of Inuit in Rankin Inlet led to the development of their own dialect.

On the other hand, not everything was idyllic. Aside from the relations among the different Inuit groups, which were problematic (Ittinuar 2008: 47-48; Williamson 1974: 115-116), there were also the relations between Inuit and Qallunaat (European), which likewise could be difficult. Ittinuar mentions that the "relationship between the qallunaat and the Inuit was quite good in the beginning. It deteriorated in the sixties when work for the Inuit fell off. Then there was like a second-class type of hierarchy" (Ittinuar 2008: 40). Moreover, like everywhere else in the Canadian mining industry at the time, there were no accident compensation programs to help miners who 
had become injured or sick and thus unable to work. There were medical services, but employees needed to pay for them (MacPherson 2003: 11). For example, after a hunting accident, Ollie Ittinuar could not work at the mine for several months. This had dramatic consequences for his son, who had little to eat during that period (Ittinuar 2008: 51-53).

The mine closed in 1963, bringing hard times to the community and its residents. According to Ittinuar (2008: 39), "When the mine shut down, problems started to settle in." After the closure, several Inuit families moved out to work at the Lynn Lake nickel mine in Manitoba. Most of them, like Ollie Ittinuar, did not speak English. Nonetheless, they were able to become foremen: "It was just that they were very good miners. They were very good workers. They were from another age of Inuit who worked hard" (Ittinuar 2008: 70). He also explained that their traditional way of life had adequately prepared them for work in the mine: "They were welcome in the miners' community" (Ittinuar 2008: 68-70). Twenty-five families from Rankin Inlet moved to Lynn Lake over the ten years following the mine closure (McPherson 2003: 14-15). A more recent study shows that the Rankin mine is still very much in the community's thoughts and is fondly remembered by some people as a better time (Cater 2012; Cater \& Keeling 2013).

While no follow-up studies were conducted on the socio-economic impact of the Rankin mine closure, a second wave of mine development has benefited from a more elaborate regulatory framework that has led to the publication of follow-up studies that identify issues regarding the development of mining in Inuit Nunangat. Such studies exist for the Voisey's Bay mine in Labrador (Archibald \& Crnkovich 1999; Labrador West Status of Women Council, and Femmes francophones de l'ouest du Labrador 2004), as well as for the Nanisivik mine near Arctic Bay (Brubacher and Associates 2002; Lim 2013; Tester et al. 2013), and the Polaris (Bowes-Lyon et al. 2009; Green 2013) and Jericho mines in Nunavut (Brubacher Development Strategies Inc. 2009). In Nunavik, follow-up reports have been published about the Raglan mine's impacts on the communities of Salluit, Kangiqsujuaq, Puvurnituq, Quaqtaq, and Kangirsuk (Lanari et al. 1999a, 1999b, 2000a, 2000b, 2000c). Most of the studies have relied on surveys of Inuit workers and members of surrounding communities and are often rather limited. Nonetheless, they provide a welcome overview of the impacts and benefits of northern mines.

For example, all of the above follow-up studies concur that Inuit employment rates have always been lower than initially predicted and that these rates have often declined after the construction phase (Bowes-Lyon et al. 2009: 319; Brubacher and Associates 2002: 17). For example, the initial aim of the Nanisivik mine's proponents was a workforce that would be at 
least $60 \%$ Inuit. In reality, this figure never exceeded $25 \%$ and remained $20 \%$ on average (Lim 2013; Midgley 2012). In the case of Raglan, the initial certificate of authorization provided for a $20 \%$ Inuit workforce (Government of Québec 1995: condition 29), whereas this rate has never exceeded 17\% (Bossous et al. 2011). Employee turnover rates have also been high, being $106 \%$, on average, at Nanisivik (Hobardt 1979), and 70\% at Raglan (O'Reilly \& Eacott 1999-2000). In some cases, contracts have been given to local Inuit companies. This was the case at the Polaris mine where "local entrepreneurs took advantage of the presence of the mine to open businesses" like shuttle and hauling services (Bowes-Lyon et al. 2009: 383-384), and at the Raglan mine through Nuvumiut Developments Inc. (Blais 2013; Blais 2014), but not so at the Nanisivik mine (Brubacher and Associates 2002: 20).

Otherissuesidentified in follow-upstudiesinclude training opportunities, impacts from work shift schedules, and poor condition or shortage of housing. The mining companies have usually offered the Inuit workers training, but the Inuit have not always been interested in the jobs made available to them because many do not see a future in mining (Bowes-Lyon et al. 2009: 379) and would rather study in fields of their own choice (Rodon et al. in press). They seem to like on-the-job training that opens up chances for promotion (Brubacher Development Strategies 2009: 39-43). Most of the studies mention impacts on the family, notably separations when men leave their home communities to work in the mines (Brubacher Development Strategies 2009: 52; Lanari et al. 1999a: 13), and a rise in family violence (Labrador West Status of Women Council and Femmes francophones de l'ouest du Labrador 2004: 55; Barrett-Wood et al. ND). An increase in problems with drug and alcohol consumption is likewise regularly mentioned (Bowes-Lyon et al. 2009: 384; Brubacher and Associates 2002: 12, 13; Lanari et al. 1999a: 13, 1999b: 12, 2000a: 13; 2000b: 58). Housing is also a big issue. In the case of Voisey's Bay, for example, accommodations were still available even after the mine had opened, but the rent was prohibitive and the overall condition of housing very poor. For this reason, the coming of the mine did not solve problems with overcrowding (Labrador West Status of Women Council and Femmes francophones de l'ouest du Labrador 2004: 29).

The follow-up studies have found higher incomes in communities where mining jobs are available. With more money, people can buy better equipment for subsistence hunting and fishing (Bowes-Lyon et al. 2009: 382; Lanari et al. 2000c: 10). These studies have noted, however, fears about the mines' impact on the environment (i.e., animal disturbance, windblown dust, chemical spill, etc.), as well as cultural fears such as loss of the language or loss of knowledge needed for traditional activities on the land, especially 
when the mines are in the vicinity of existing communities (Brubacher and Associates 2002: 8).

These studies say nothing, however, about the impact of mining developments on health and family cohesion. Fortunately, some Inuit are beginning to talk about this, such as Carol Kunnuk, who grew up on the Nanisivik site in North Baffin Island:

I was four years old when we moved to Nanisivik. When my dad got a permanent job at the mine, we were given housing and so we moved there. $[\ldots]$

That's the first time I've ever known a very wealthy place. It had everything: furniture, places to eat, swimming pools, theatre nights, fitness rooms, gymnastics and marathons every year; it was very modern life compared to here. And running water, tvbecause in Igloolik we still had honey buckets and only radio, no phone. It was like a dream, but when I talked about it with my parents, years later, they tell me it really happened like that. Such a sudden change; a culture shock.

So I got used to modern life with white people; the way they lived; the way they talked. Most of the people who moved up there came from Newfoundland, and so I understood Newfie more than Inuktitut. But then my parents didn't speak English at all; they only spoke Inuktitut. And they would joke around, make fun, say I'm such a white, white style, that I don't know anything about their culture or who they are, I don't know how to eat meat. Small stuff like that, but it was very painful for me. So it was a confusing life, between my culture and white culture.

I wasn't home a lot. I had better things to do, like sports, and that kept me distracted. Also, there were stores, we had the dome, which was the place where all the people of Nanisivik went for breakfast, lunch, supper - we were given three meals because our parents lived there-but there were lots of parties. Lots of alcohol, too. I don't know anything about drugs but lots of alcohol. And my parents became alcoholics from living up there. My mother, that's how she got cancer-from alcohol-because she became such an alcoholic.

I don't know what else to say. Racism. Family abuse. Sexual abuse. That place practically destroyed our family. It's difficult for us to talk about. (Carol Kunnuk in Gaul 2012a) 
Finally, the follow-up studies have provided almost no information on the impacts of mine closures. People have scarcely begun to think about this aspect of the mining cycle. This is the case with the Nanisivik mine closure, the impact of which has been recently documented (Lim 2013). Unlike the closure at Rankin Inlet, the one at Nanisivik left, above all, bitter memories in Arctic Bay, largely because the infrastructure was destroyed due to the company's fear of liability issues, even though the community had wanted to take over the housing units and athletic facilities (Rideout 2002).

\section{Comparing the Ragland and Meadowbank Experience}

The Raglan nickel mine (1997) and the Meadowbank gold mine (2010) are the only mines in Inuit Nunangat that have been in operation for a few years and therefore allow us to understand their social and economic impacts on surrounding Inuit communities.

The Raglan mine is inland from the south shore of Hudson Strait, near Deception Bay in Nunavik. The Inuit of this region signed the first Canadian modern treaty in 1975, the James Bay and Northern Quebec Agreement (JBNQA). Raglan began operating in 1998 under the ownership of Falconbridge, ${ }^{1}$ following issuance of an initial certificate of authorization (ICA) by the Quebec government in 1995. According to the certificate's conditions, the mine is committed to making its workforce $20 \%$ Inuit (Quebec Government 1995: condition 29). In 2008, knowing this target was proving hard to reach, Raglan developed the Tamatumani training program, which aimed to attract, retain, and integrate Inuit into the mine's workforce (Dansereau 2011: 2). Despite this program, the Inuit employment rate has remained around 16\% throughout the mine's life (Bossous et al. 2011).

Raglan owners have also been bound by commitments negotiated in the Raglan Agreement, the first Canadian bilateral Impact Benefit Agreement (IBA). It was signed in 1995 by Société Minière Raglan du Québec Limitée (a Falconbridge subsidiary), by the Makivik Corporation, by the northern villages of Salluit and Kangiqsujuaq, and by their respective landholding corporations. This IBA aims to reduce environmental risks and define the parties' responsibilities and benefits (Benoit 2004: 13). Among other things, it assigns $4.5 \%$ of the mine's profits to the communities of Salluit (which receives $45 \%$ of this amount) and Kangiqsujuaq (30\%), and to the Nunavik region (25\%) (Kativik Regional Government 2007). This provision has led to significant financial benefits. Since 1997, Raglan has paid out just over \$100 million in royalties to Nunavik (George 2012). 
In addition, this redistribution of mining royalties varies from year to year, in line with the communities' wishes. Every year, James Bay and Northern Quebec Agreement beneficiaries in each of the two communities are asked to vote on how the money should be distributed. Salluit beneficiaries have generally voted for having the royalties paid directly to them, whereas Kangiqsujuaq beneficiaries have instead opted to invest the money in community projects (Blais 2014). This being said, nothing guarantees that the current system will stay unchanged. Over the last few years, Salluit has been paying out less to individuals and spending more on community projects, partly to ensure that the money remains in the communities rather than being spent on goods purchased from elsewhere (Blais 2014). Direct distribution of royalties to individuals is a major issue. Many Inuit feel this enables them to improve their material conditions of life. Yet, as some studies have stressed, this system of redistribution generates only weak positive benefits and may even have negative implications or outcomes in terms of long-term health and well-being (Knotsch et al. 2010: 65-66).

Today, Meadowbank is the only mine in operation in Nunavut. Jericho diamond mine and Meadowbank gold mine were the first mines to operate after the signing of the Nunavut Land Claims Agreement (NLCA) in 1993 and the creation of Nunavut in 1999. The Meadowbank mine is located $70 \mathrm{~km}$ north of Qamani'tuaq and started production in 2010. Article 26 of the NLCA requires project developers to negotiate an Inuit Impact and Benefit Agreement (IIBA) with regional Inuit organizations. IIBAs have to offer compensation, royalties, local employment and training, and ensure contracting to Inuit businesses. Therefore, Meadowbank started production after obtaining approval from the Nunavut Impact Review Board (NIRB) and signing an IIBA with the Kivalliq Inuit Association; however, the financial measures are confidential and have not been disclosed.

The testimonies analyzed here come from various sources. Although Meadowbank has been in operation for only five years, more studies have been conducted on its social impacts than have been on those of Raglan. For this reason, the social and economic impacts of Raglan are mostly analyzed through interviews conducted with forty-six participants during the autumn of 2012 in Kuujjuaq, Salluit, and Kangiqsujuaq ${ }^{2}$ as well as follow-up studies made public more than a decade ago (Lanari et al. 1999a, 1999b). The 2012 interviews showed that the impacts from Raglan are similar, on almost all aspects, to the ones identified in the late 1990s. The social and economic impacts of Meadowbank are analyzed through qualitative evidence gathered over the course of the past five years by various researchers. This information has been made public in Masters theses (Bernauer 2010; Peterson 
2012; Laneuville 2013), reports (Bernauer 2011; Bernauer 2012; Czyzewski et al. 2014; Knotsch et al. 2011), and journal articles (Dana and Anderson 2014). These documents shows that although Qamani'tuamiut experiences of Meadowbank are not homogeneous, they are similar in many aspects to those expressed by Salluimiut and Kangiqsujuamiut.

In the following sections, we will examine a series of eight positive and negative impacts experienced by Inuit in Salluit and Kangiqsujuaq in Nunavik, and Qamani'tuaq in Nunavut. Although some of those impacts are specific to one community or the other, most are found in all three.

\section{Positive Economic Impacts}

For many, the influx of money in all three communities has had positive impacts. In the case of Raglan, interviewees mention that the mine has provided Salluimiut and Kangiqsujuamiut with very substantial economic opportunities. Even though the mine has failed to hire enough Inuit to meet its initial commitments, it offers what many called "good jobs" that pay a lot more than do the few jobs available in their communities. Several interviewees pointed out that the jobs are also ego-boosting and that they were proud to have them. On top of this direct employment, the mine's presence has also helped create indirect employment. For example, in Salluit, "the landholding hires 10 Inuit" (SA-21). ${ }^{3}$ Similarly, in Kangiqsujuaq, the royalty money has paid for the opening of a gymnasium that employs five people full-time and a hotel that gives work to three people. There are also plans to open a garage that will hire two people (KA-19).

Meadowbank has an important economic influence on Qamani'tuaq. Although the mine does not pay royalties directly to individuals, ${ }^{4}$ many Qamani'tuamiut benefit from direct employment at the mine or from indirect employment with the local companies who are under contract with the mine (Peterson 2012: 79-84). In 2010-2011, 232 Inuit beneficiaries were working at the mine, 132 of whom were from Qamani'tuaq (SEMC 2011). Their number increased to 289 in the following year, 152 of them from Qamani'tuaq (SEMC 2012), which represented 52.6\% of Inuit employed at the mine. However, although mining jobs are perceived as having positive impacts on individuals and their families, trained workers leaving other community jobs to work at the mine has a negative impact on the delivery of municipal services (Knotsch et al. 2011: 5). Most Inuit employed at the mine work in the kitchen, in housekeeping, or in laundry services. There are few Inuit machinery operators and miners, and no Inuit hold executive jobs. 
The income of Qamani'tuamiut with direct or indirect jobs from the mine has tangible social impacts on the community. Silas Aittauq mentions, for example, that life is easier for him since the mine has provided work for his children and grandchildren who previously depended on him (quoted in Bernauer 2010: 87). Others also mention that the increase in income improved the well-being of many people since it allowed them to buy food and other things they needed for their everyday life like furniture, new winter clothing, and other essential goods kids may need (Czyzewski et al. 2014: 55; 69-71). One Qamani'tuamiut mentioned that when paycheque come in, "you can go down to the Northern and see shopping carts full with whatever they want to buy. They have an opportunity to provide for their families and that's a really good part [of having the mine]" (quoted in Peterson 2012: 75).

\section{Negative Social Impacts}

The presence of more money may be beneficial, but is also a mixed-blessing in all three communities. Kangiqsujuaqmiut and Salluimiut stated that the new sources of income, mostly in the form of royalties and salaries, have led people to consume more alcohol and drugs. This consumption has negative impacts on the community's members because it reduces the quality of life for those who do not consume; affects families; and leads to accidents, conjugal violence, and cases of sexual abuse (SA-17). This problem is not recent. The same observation was made when a team produced studies on the Raglan mine's social impacts for the Makivik Corporation in the late 1990s (Lanari et al. 1999a: 13-14, 1999b: 12-13). The problem is worsened by the fact that the mine employees, who are prohibited from consuming alcohol or drugs during their work period, make up for lost time when they return to their community by bringing substances illicitly bought at the mine site, and by consuming alcohol mailed to their home address (Blais 2014: 49).

Surprisingly, royalties distribution tends to dampen economic activity in the communities. Several interviewees noted that the arrival of royalty cheques paralyzes the village economy for a few weeks each year. A Kangiqsujuaq woman recounted: "when the cheque arrives, it's difficult since nobody wants to come to work, for example this summer, the daycare has been closed almost all summer because the daycare workers had their Raglan cheque" (KA-09). The situation is similar in Salluit: "When the Raglan cheque arrives nobody goes to work" (SA-23). 
This mixed feelings about economic impacts are also present in Meadowbank:

There are blessings given to us from the mine and yet a mixture of, um, misfortunes, I would suppose that's the word. Um, we've been able to, um, get new things; not all the time, but more food, more camping supplies. It supplied us with hunting and fishing in a better way. And yet it's given us enough to supply for alcohol and it encouraged us a little bit more to enjoy with friends. (quoted in Czyzewski et al. 2014: 54)

Income from jobs increases economic inequalities between individuals (Czyzewski et al. 2014: 52-53; Peterson 2012: 79), encourages reckless spending and, more importantly, exacerbates abuse of alcohol and drugs (Bernauer 2010:129). This is easily measured since access to alcohol is restricted in Qamani'tuaq. In order to import alcohol, one has to get a permit from the RCMP: 3,000 permits were issued in 2009, and 6,105 in 2011 (Czyzewski et al. 2014: 73-74; Peterson 2012: 97-101). This is especially problematic since, according to Czyzewski et al., there are few programs designed to assist people with alcohol addiction in the community (2014: 80-83). Research also suggests that addictions to alcohol and drugs have important social impacts since this leads to more violence and harassment (Czyzewski et al. 2014). This was visible in the increased number of police files the community saw between 2008 and 2011-from 540 to 800, an increase of 22.5\% (Czyzewski et al. 2014: 65).

\section{Impact on Municipal Infrastructure, Housing, and Public Services}

Raglan is a self-contained mine with its own airport, housing, and entertainment infrastructure, so the workers have no impact on the community infrastructures. However, royalties distribution has an impact on public service since in the years when the amounts are quite significant, many people quit working and services like daycare, water delivery, and sewage pick-up are disrupted (Blais 2014). One Kangiqsujuamiut mentioned that when the cheque comes during the summer, "many people will leave the town to go out camping and do stuff like taking drugs. It's tough to find people to replace them at work. At one point, I was working by myself. I even got locked out of the office once because everybody was gone" (KA-07).

Meadowbank is also a self-contained mine, but is connected to the Hamlet of Qamani'tuaq by a road so it has direct impacts on its infrastructure, especially the number of available houses. Indeed, the jobs 
offered by the mine and local businesses bring a number of Nunavut Inuit to the community. This led to an increase in the community's population from 1,728 in 2006 (Peterson 2012: 93) to 1,865 in 2011. ${ }^{5}$ Yet, the number of new houses built on a yearly basis is not sufficient so there are not enough houses to accommodate everyone. One Qamani'tuamiut mentions that:

There's a family, a relative of mine in a small three bedroom house. I think sometimes there's up to 20 people in a house. That's been going on almost 6 months now maybe 8 months, and there's no way to look into that kind of problem. Overcrowding causes a lot of problems in the homes. Health reasons and other personal problems. (Quoted in Bernauer 2010: 129)

\section{Work Schedule}

The experience of the work schedule is similar in all three communities. In Meadowbank as well as in Raglan, most of the jobs available are on the mine site. This requires Inuit to live on-site for a two-week period before they can go home for two weeks. This schedule is, however, positively perceived by some people because it provides a break from work and/or from home. For example, a Salluit woman mentioned that she feels less stress at the mine site because she no longer has to take care of her grandchildren and make meals (SA-17) Also, because of the crammed housing situation in the three communities, some prefer having a room at the mine site rather than living in their overcrowded homes. One Inuk from Kangiqsujuaq said that when she was living with her parents, "it was hell [...]. Well, maybe not hell, but there were no apartments in town and it was too much for me. At Raglan, I have my own room" (KA-13). The employees are not the only ones to feel relieved. The families back home may also be glad to have one less mouth to feed during the work period (KA-19).

This set-up is not, however, to everyone's liking. It can be very hard on young couples with children. One interviewee mentioned that "Inuit are close to one another and when we have children or a wife, we want to be with them and not be gone for two weeks where we can miss birthdays or other things like that" (SA-18). Some will even go so far as to quit their jobs in order to be close to their loved ones. Others say it is often very hard for a woman who stays home alone for two or three weeks to take care of all the children. This set-up also has indirect impacts. For example, it is the cause of school absenteeism. When the parents finally come home to the community after their work period, their children "don't want to go back to 
school because they want to stay home with their mother or father, who they haven't had a chance to see" (KA-09).

This work schedule is also problematic for many Qamani'tuamiut. Because there are no daycares available in the community for single parents who would like to work at the mine, this prevents them from applying for jobs and thus keeps single parents from working at the mine (Bernauer 2012: 11). The schedule is also extremely difficult on couples. In fact, some Qamani'tuamiut suggest that since the opening of the mine, there has been an increase in extramarital affairs and relationship breakdown in the community (Czyzewski et al. 2014: 63-66; Paterson 2012: 71) .

\section{Turnover Rates}

The turnover rates ${ }^{7}$ for Inuit employees are high in both mines. At Raglan, turnover rates were around $70 \%$ in 2000 compared to $15 \%$ for other employees (Keller 2012). It has decreased with the creation of the Tamatumani program, but turnover rates for Inuit employees in 2013 were still ten times higher than the rate for non-Inuit employees (Jourdren 2014).

At Meadowbank in 2011, the turnover rate was 27\% (Paterson 2012: 45). This high turnover can first be explained by the fact that many employees do not like their jobs and find it extremely difficult to get promotions (Peterson 2012: 68-69). Many employees are promised advancement when they are hired, but few of these promises are met (Czyzewski et al. 2014: 43). ${ }^{8}$ Second, it may also be explained by the fact that many employees seek other employment opportunities with exploration companies. In Qamani' tuaq, the Kiggavik Project has drawn its share of workers from Meadowbank (Bernauer 2012; Paterson 2012). In Nunavik, the opening of a second mine (Canadian Royalties) and a large number of exploration projects also draw a fair share of workers out of Raglan. Finally, many Inuit have the feeling that working at the mine is detrimental to their culture and language. For example, their schedule may prevent them from going hunting or participating in other cultural activities. One Qamani'tuamiut mentions that because of his job, he:

... would work only during the summer and go back to traditional hunting in the winter. There was once or twice I tried asking 'hey, I want to go back home because I want to catch some caribou and do some caching before the winter sets in', but I was told no. I continued until we got done. I couldn't do any hunting what-soever. My grandmother had said, ‘hey, because you don't hunt that often and because you're working all summer during the good hunting season you'll have no cache and there will be times when 
there are no caribou around. Your children, your wife, are all going to become hungry during those times. You'd might as well move to the community.' So I did. (Quoted in Bernauer 2010: 19)

\section{Concerns about Environmental Problems}

Both mines have had significant environmental impacts, from dust to the migration of caribou herds, that have had significant social effects on the Inuit of all three communities. Several Nunavimmiut said the mining activities have affected their health and the health of the animals they eat. It is worth noting, however, that since the late 1990s the Inuit have changed somewhat in the way they perceive the mine's environmental impacts. At that time, many people were optimistic about the mine's effects and felt that the former mine owner, Falconbridge, had been prudent. The Inuit notably appreciated being consulted about environmental matters (Lanari et al. 1999a: 3-4, 1999b: $3-4)$. It must be said that many local Inuit clung to bad memories from the Asbestos Hill mine, which had operated in the region in the 1970s and had left a lot of waste and contaminants in the environment. Falconbridge's receptive attitude encouraged them to think the situation would not be repeated. Nonetheless, some Inuit were already voicing criticisms about the mine and feared the impact some oil spills would have on the fish (Lanari et al. 1999a: 5-6).

In 2012, the Inuit were still afraid that mining activities were contaminating the fish, the streams, and the rivers. One Salluimmiut mentioned that:

\footnotetext{
Some people in the village became sick after eating fish taken near the mine site. We gave them to Makivik for analysis, but we have no proof. For example, my real mother, I gave her fish and she was poisoned. She's an elder now, and she stopped eating fish ... She's afraid of being sick. I eat some fishes, but not often, they have a taste ... they taste like tobacco. (SA-21)
}

Another added that "some fishes have huge heads, small bodies ... That's what we see" (SA-02). An Inuk from Kangiqsujuaq added he was also worried about all of the animals that wander near the mining facilities, like caribou and snow geese (KA-10). Whether founded or not, this fear has led some elders to eat less fish and caribou. ${ }^{9}$

Some people also wonder about the effect of chemical products used by the mine. One Inuk worried that "the chemicals used at the mine are poured in the water and that this water intoxicates fishes. Can you imagine, this 
mine is working seven days a week and has 400 employees ... How much water is used? Rivers are not pure, not natural anymore" (SA-21). Some even went further and looked forward to seeing the mine close:

I can't wait for Raglan to close. Because of our environment. The extractor never stops, 24 hours. It never stops. I hate that! It bothers fishes, sea mammals, all the animals, even clams in the bay. I love country food, it's my priority, even for my generation. Because I don't want the other generation to only eat chocolate bars and chips (KA-13).

Environmental impacts are seen as having an impact on food security. First, the contaminants and dust from the mine have brought about changes to traditional habits. One person mentioned there is now "a lot of dust on the snow and with the sun, it's black and warmer, so the snow melts faster. We could go fishing near the mine before until the second week of June by snowmobile. But now we lose a month. In the second week of May, we can't go anymore" (SA-21).

Mining activities have also led to environmental degradation that is forcing the Inuit to change some of their habits for fear of adverse consequences. One non-Inuit community member attested to the fact that hunters sometimes have to:

... use different migratory paths because the ice has been damaged. Before I used to go through there, but now, to go to a lake, I have to choose another way and it's dangerous. We've already lost a member of our community. (KA-19)

In Meadowbanks, environmental impacts are not experienced as they are in Nunavik. For example, some think that the mine does not affect caribou (Laneuville 2013: 113). An informant of Qamani'tuaq mentions that:

The only thing I sort of opposed was the building of the road. But I stopped opposing it when I heard that caribou will cross the road, will go wherever they want, cross the road whenever they want. Once they want to move, not even the road will stop them. That's when I stopped opposing the building of the road. I have nothing against them [the mining company] as far as I know. (Quoted in Bernauer 2010: 87) 
Yet, Qamani'tuamiut have different ideas as to whether or not the road and the mine affect caribou populations. On one hand, some claim caribou are deeply affected because the animals have problems crossing the road, especially in winter when the road plowing pushes high packs of snow to both sides of the road (Bernauer 2012: 8; Czyzewski et al. 2014: 99). On the other hand, some elders also claim that caribou are able to adapt (Laneuville 2013). What people agree on, however, is that the road causes clouds of dusts that did not exist before (Bernauer 2012: 8; Paterson 2012: 103). These dust clouds affect berries but, most importantly, get into the water system. For this reason, many Qamani'tuamiut say that fish is contaminated and refuse to eat any from specific lakes (Bernauer 2012: 8). Some Qamani'tuamiut are also concerned about the barges on the lake in front of the community (Paterson 2012: 104) and about waste management. One Qamani'tuamiut mentioned that:

We used to be able to walk on the tundra, and seeing what has happened now; you know, they destroyed the land, not only the surface, but way under the ground as well. (Czyzewski et al. 2014: 100)

\section{Cultural Impacts}

Both mines have impacts on the capacity of Inuit to carry out cultural activities. The most obvious impact is on the ability of mine employees to participate in the traditional economy-hunting, fishing, and trapping activities - since the Inuit working a two-week shift might miss the passage of belugas, caribou, or walrus near the community, missing the opportunity to stock up on country foods. An Inuk from Salluit mentioned that:

... a lot of people don't like to be up there because they get to be away from their families and when they're up there, two weeks, three weeks, they don't go fishing, they don't go hunting walrus. A driver here, they go hunting every weekend if the weather is good. So, here, people like to have a job at home. (SA-12)

However, cultural impacts are not only negative. Indeed, the extra income is used by many to buy hunting equipment, including weapons, ammunition, fuel, and vehicles to go out on the land. These are beneficial for many people to provide harvested meat for their families (Peterson 2012: 75; Bernauer 2010: 127). In Qamani'tuaq, the road that links the site of the mine to the community also has impacts on the local population's culture. 
Although hunters are required to get a permit, they say the road facilitates hunting practices by offering easy access to hunting grounds. Some others are not quite as sure. Some Qamani'tuamiut say people seem to hunt less (Bernauer 2010: 129) or mention that the road impacts the number of caribou (Laneuville 2013). For this reason, their hunting patterns have changed (Peterson 2012: 106).

In Qamani'tuaq, the mine also has cultural impacts for it was built on a site where many Qamani'tuamiut were born. On the bright side, this allowed many of those born there to go back and, as such, it reactivated the site and gave it back a legitimacy it had lost to many local Inuit (Laneuville 2013). However, building the mine on that site has also been problematic for some individuals. For example, the mine's kitchen was built above a former burial ground. Some Inuit mention that strange phenomena, likely caused by unhappy tuurngait (spirits, shaman helpers) and ijirait (polymorphic giants), happen in the kitchen, and they are therefore reluctant to work there (Laneuville 2013).

\section{Mining Royalties Distribution}

Mining royalties distribution is quite different in Meadowbank and Raglan. In Meadowbank, all royalties are paid to the Kivalliq Inuit Association and are distributed to various programs. In Nunavik, there is an agreement between Makivik, Kangiqsujuaq, and Salluit that sets the sharing of royalties. Makivik receives 25\%, Kangiqsujuaq 30\%, and Salluit $45 \%$. Each community decides by annual referendum how royalties will be distributed.

All of the 2012 Nunavik interviewees agreed that the impacts have been positive when the money is given to the communities and also administered by the communities. The effects have been less positive when the money

goes directly to individuals. In both Salluit and Kangiqsujuaq, the royalties have been used to build or renovate infrastructure thought to be essential. For example, an Inuk from Salluit observed that:

With what we receive from the mine, we built infrastructures in Salluit. For example, we built a church. The pool that will open in a couple of weeks has been paid $80 \%$ with the royalties. Both gymnasiums at school, it's with Raglan's money. The arena, it's bigger than in other villages because we have royalties from Raglan, we said 'we want a gym. We want artificial ice.' (SA-21)

This observation is even more valid in Kangiqsujuaq, where a greater portion of the royalties has been administered by the community and used to build 
local infrastructure. In this community, "royalties have been reinvested in the community: we built a gym, renovated the arena, built a pool, a hotel, an elder's residence, we invested in small businesses ..." (KA-19).

When paid directly to individuals, the royalties are often associated with better conditions of life because they provide the means to buy vehicles (such as snowmobiles, trucks, boats, ATVs) as well as hunting and fishing equipment that make it easier to engage in traditional activities. Thus, in Salluit, an interviewee attested to the fact that "there's more trucks now than there used to be. Every year, there are more snowmobiles ... Life is better for most" (SA-21). In Kangiqsujuaq, some have come to realize that royalties encouraged the return of traditional activities. One man said that "it's easier to get on the land now with snowmobiles bought with mine money; fuel is not as expensive so we go hunting more often and we spend more time inland as well" (KA-19).

These words were corroborated by an Inuk from the community, who said that because of its high costs, "fishing activities would stop without Raglan's money" (KA-01). The royalties are used for buying not only fishing and hunting equipment, but also furniture and household appliances that would otherwise have been too expensive. Several people thought the royalties and mine jobs have helped improve the lives of Inuit in both communities.

As we can see even if royalties distribution allows community members to purchase goods, it also creates numerous problems. Furthermore, the capacity of Inuit communities to capture and keep resource rent is clearly an important issue (Kulchyski and Bernauer 2014). Finally, a study conducted in US Indian reservations that operate a casino shows that reservations where casino profit is distributed to individuals have higher poverty rates than reservations that socialize the profit (Guedel 2014). In other words, money distribution doesn't often translate into wealth. A similar pattern has been identified in communities near Raglan (Rodon et al. 2014).

\section{Conclusion}

The socio-economic impacts identified in this paper are quite similar in the three communities studied: some positive impact with the availability of jobs, higher incomes, construction of infrastructure that benefit the community, and access to the land (roads). Furthermore, in the case of Meadowbank, some Qamani'tuamiut mention that the mine has increased the sense of power of the community (Peterson 2012: 114), and given them the experience to negotiate with future mining companies (Bernauer 2010). Indeed, many 
Qamani'tuamiut are not against mining, but they want to develop this industry on their own terms and have more control over these developments (Dana et al. 2014). There are, however, numerous negative impacts in all three communities, such as drug and alcohol abuse, environmental contamination, disruption of the land-based economy, impact on culture and family life, employee turnover, and so on.

Finally, we also have to consider the long-term environmental and cultural consequences of mining activities. For example, a Salluimiut wondered whether the millions of dollars in royalties and wages have really been worth it. One individual mentioned that "despite the money they're giving us, they must respect us. They must respect life because mines have a life. At one point, they'll say they have no more ore and quit, but we'll stay here" (SA-21).

The perceptions of the mining's impacts therefore seem to remain the same over time and between the two regions, in spite of the fact that Inuit communities are now consulted and Inuit organizations have more control over mining development through the land claim organizations and the IBA processes. However, it remains to be seen if Inuit communities are now benefiting economically more than before from mine development. Unfortunately, there are no socio-economic studies that can be used to measure the net benefit precisely. We can nonetheless say that mining companies have difficulty reaching their employment targets, that Inuit make up a declining proportion of the mine workforce, and that turnover rates remain quite high. This is because in the 1950s one could not easily "flyin and fly-out" the miners needed. Now, however, this practice has become the norm for northern mines, and local workers are no longer so necessary. In addition, the mining profession has changed a lot over the years. Mines have gone from primarily manual jobs that required little education and much physical ability, to skilled trades that require higher education and proficiency in complex technologies.

The different accounts presented here provide a mixed picture. The mines bring extra income, yet their presence does not necessarily create sustainable economic development in the communities. Resolute Bay, Arctic Bay, Salluit, and Kangiqsujuaq may have benefited from employment, new community facilities, and a lower level of social assistance expenditures than in other communities (George 2012); but, as we have seen with Resolute Bay and Arctic Bay, the mines left little more than mixed memories after they closed. Also, the payment of royalties directly to the population has had dubious effects. While some have used the money to buy equipment and to engage in subsistence activities, in other cases the money has been spent rapidly 
and with little benefit to the communities. Above all, the influx of money has had a major impact on public services and little apparent impact on local economic development, although we need more studies of the real economic benefit created by mines in remote Arctic communities. It has been shown that sustainable economic development depends partly on communities taking charge of such development (Cornell \& Kalt 1998; Humphreys 2002). Yet, within the Canadian and Quebec institutional framework, the communities feel they have little control (George 2013), even though many Inuit communities are demanding more control over resource development taking place on their ancestral lands.

\section{Acknowledgements}

Authorization to conduct the interviews used for the section on Raglan in this article was obtained from the Makivik Corporation, the northern villages, and the landholding corporations of Salluit and Kangiqsujuaq as well as the Laval University Ethics Board (CERUL). Research and fieldwork were funded by a grant from the MRN (Québec Department of Natural Resources) and by the Northern Sustainable Development Research Chair. We finally want to thank Jonathan Blais, Louisa Pauyungie, and Elaisa Uqittuq who conducted the interviews in Salluit and Kangiqsujuaq.

\section{Authors}

Thierry Rodon is an assistant professor of political science and director of the Centre interuniversitaire d'études et de recherche autochtone at Laval University where he holds the Northern Sustainable Development Research Chair.

Francis Lévesque is an assistant professor at the Unité d'enseignement et de recherche en sciences du développement humain et social, Université du Québec en Abitibi-Témiscamingue (UQAT).

\section{Notes}

1. Raglan was taken over by Xstrata in 2006 and has been part of Glencore since 2013.

2. These interviews were conducted in order to understand the social impacts of the Raglan mine. With assistance from Inuit co-researchers, they were held with former mine workers, landholding corporation employees, health care workers, police officers, Makivik Corporation employees, and Nunavik Mineral Exploration Fund employees, among others.

3. To protect interviewee anonymity, as requested by the interviewees themselves, each of them was assigned a coded ID (KA: Kangiqsujuaq; KU: Kuujjuaq; SA: Salluit). The quoted extracts come from Blais (2013). 
4. Meadowbank's IIBA did create a scholarship fund of $\$ 14,000$ a year, but as of 2013, there is no indication of any "spending on community initiatives made possible by royalty payments made to KIA [Kivalliq Inuit Association] on behalf of community residents in the region" (Czyzewski et al. 2014: 33).

5. Statistics Canada. 2013. Baker Lake, HAM, Nunavut (Code 6205023) (table). National Household Survey (NHS) Profile. 2011 National Household Survey. Statistics Canada Catalogue no. 99-004-XWE. Ottawa. Released September 11, 2013. Accessed October 23, 2014. http://www12.statcan.gc.ca/ nhs-enm/2011/dp-pd/prof/index.cfm?Lang=E.

6. A literature review of mining and Aboriginal community health has actually shown that rotational work shifts have impacts in the areas of fatigue and work performance, mental health, spousal and relationship conflicts, children, community health, and cultural continuity (Barrett-Wood et al. 2012).

7. Turnover rates are represented by the number of employees that terminated their employment divided by total employees.

8. Peterson (2012: 69) suggests that this can be explained by the fact that promotions require employees to highlight their work records, which very few Inuit do for fear of seeming prideful and arrogant.

9. The Nunavik Research Centre has produced a summary of the different studies on Arctic char between 1951 and 2001. These studies do not prove that the Raglan mine's activities have had impacts on Arctic char populations in its vicinity (Simard 2004).

\section{References}

Abele, Frances. 2009. “Northern Development: Past, Present and Future.” In Northern Exposure: Peoples, Powers and Prospects in Canada's North, edited by F. Abele, T. Courchene, F. St. Hilaire et L. Seidle, 19-65. Montréal: Institute for Research on Public Policy.

Archibald, Linda, and Mary Crnkovitch. 1999. If Gender Mattered: A Case Study of Inuit Women, Land Claims and the Voisey's Bay Nickel Project. Ottawa: Status of Woman Canada.

Asselin, Hugo. 2011. "Plan Nord. Les Autochtones laissés en plan." Recherches amérindiennes au Québec XLI(1): 37-46

Barrett-Wood, Zoë, Kathleen Knotsch, Colleen Davison, and Ben Bradshaw. 2012. Translating Knowledge on Impacts of Mining for Aboriginal Community Health: The Issue of Rotational, Two-Week Work Shifts. Poster presentation, IPY 2012 Conference Montreal, April 22-27, 2012, Montreal, Quebec.

Benoît, Catherine. 2004. L'entente Raglan: Outil efficace pour favoriser la formation et l'emploi Inuit? Évaluation et documentation de la situation de l'emploi des Inuit à la mine Raglan, au Nunavik, dans le cadre de l'entente sur les impacts et bénéfices, mémoire de maîtrise, Université du Québec à Montréal, Montréal. 
Bernauer, Warren. 2010. "Uranium Mining, Primitive Accumulation and Resistance in Baker Lake, Nunavut: Recent Changes in Community Perspectives." Masters thesis, University of Manitoba, Winnipeg.

Bernauer, Warren. 2011. "Mining and the Social Economy in Baker Lake, Nunavut." University of Saskatchewan, Saskatoon: Prepared for the Northern Ontario, Manitoba, and Saskatchewan Regional Node of the Social Economy Suite.

Bernauer, Warren. 2012. “Discussion Paper: Impacts on Caribou and Inuit Harvesting of Caribou in AREVA's Draft Environmental Impact Statement for the Proposed 'Kiggavik' Uranium Mine." Baker Lake: Baker Lake Hunters and Trappers Organization.

Blais, Jonathan. 2013. Analyse des impacts de la mine Raglan sur les communautés de Salluit et Kangiqsujuaq. Supervised by Thierry Rodon and Francis Lévesque, Québec, Ministère des Ressources naturelles du Québec et Géologie Québec.

Blais, Jonathan. 2014. Les impacts sociaux de la mine Raglan auprès des communautés inuit de Salluit et de Kangiqsujuaq. Master's theses, Université Laval, Québec City.

Bossous, Martine, Caroline Siroism, and Thérèse Côté. 2011. “Tamatumani: Activités de formation à la mine Raglan." Katinniapik 5(1): 7-10. Accessed April 2015 http://www.xstratanickelraglan.ca/SiteCollectionDocuments/Katinniapik\%20 d\%C3\%A9cembre\%202010_fr.pdf.

Boutet, Jean-Sébastien. 2010. "Développement ferrifère et mondes autochtones au Québec subarctique, 1954-1983.“ Recherches amérindiennes au Québec 40(3): 35-52.

Bowes-Lyon, Léa-Marie, Jeremy P. Richard, and Tara M. McGee. 2009. "SocioEconomic Impacts of the Nanisivik and Polaris Mines, Nunavut, Canada." In Mining, Society, and a Sustainable World, edited by J.P. Richards, 371-396. Berlin: Springer.

Brubacher and Associates. 2002. The Nanisivik Legacy in Arctic Bay. A Socio-Economic Impact Study, préparé pour le Gouvernement du Nunavut, Département du développement durable, Ottawa, Brubacher and Associates.

Brubacher Development Strategies Inc. 2009. Kitikmeot Socio-Economic Monitoring Committee Jericho Diamond Mine. 2007 Socio-Economic Monitoring Report. Ottawa, Brubacher Development Strategies Inc.

Canadian Press. 2011." Harper Pitches Arctic Development.” CBC News, August 24. Accessed April 2015 http://www.cbc.ca/news/canada/story/2011/08/24/northharper-tour.html.

Cater, Tara. 2012. “'The Road to Meliadine': Exploring Past, Present, and Future Mining Encounters in the Kivalliq Region, Nunavut." Vancouver: ArcticNet Annual Scientific Meeting.

Cater, Tara, and Arn Keeling. 2013. “'That's Where our Future Come from': Mining, Landscape and Memory in Rankin Inlet, Nunavut." Études/Inuit/Studies 37(2): 59-82. 
Cornell, Stephen, and Joseph P. Kalt. 1998. "Sovereignty and Nation-Building: The Development Challenge in Indian Country Today." American Indian Culture and Research Journal 22(3): 187-214.

Cyzewski, Karina, Frank Tester, Nadia Aaruaq, and Sylvie Blangy. 2014. The Impact of Resource Extraction on Inuit Women and Families in Qamani'tuaq, Nunavut Territory. A Qualitative Assessment. Pauktuutit Inuit Women of Canada and UBC School of Social Work.

Dana, Léo-Paul, and Robert B. Anderson. 2014. "Mining and Communities in the Arctic: Lessons from Baker Lake, Canada." International Journal of Entrepreneurship and Small Business 22(3): 343-361

Dansereau, Suzanne. 2011. “Mines: La bataille des employés qualifiés." Les Affaires, 15 octobre: 24 .

Duhaime, Gérard, Nick Bernard, and Robert Comtois. 2005. "An Inventory of Abandoned Mining Exploration Sites in Nunavik, Canada." The Canadian Geographer 43(3): 260-271.

Duhaime, Gérard, Nick Bernard, and Andrée Caron. 2011. "Mining on Aboriginals Lands." In Hidden in Plain Sight, Contributions of Aboriginal Peoples to Canadian Identity and Culture, edited by C.J. Voyageur, D.R. Newhouse, and D. Beavon, 108-130. Toronto: University of Toronto Press.

Galloway, Gloria. 2011. Prime Minister Stephen Harper Pushes Mining Expansion in Arctic. The Globe and Mail, August 24, 2011. Accessed June 2012 http://www.theglobeandmail.com/news/politics/ prime-minister-stephen-harper-pushes-mining-expansion-in-arctic/article592113.

Gaul, Ashleigh. 2012a. Memories of Nanisivik: "Racism. Family Abuse. That Place Practically Destroyed Our Family." Baffinland Witness, 8 July. Accessed April 2015 http://baffinlandwitness.com/2012/07/08/memories-of-nanisivik-racismfamily-abuse-that-place-practically-destroyed-our-family.

Gaul, Ashleigh. 2012b. "Memories of Nanisivik: 'I still miss it; I can't say that enough. I'm still homesick."' Baffinland Witness, 10 July. Accessed April 2015 http://baffinlandwitness.com/2012/07/10/ memories-of-nanisivik-i-still-miss-it-i-cant-say-that-enough-im-still-homesick.

George, Jane. 2012. "Xstrata Mining Dividends Cut Welfare Rolls in Nunavik Communities." Nunatsiaq News, Sept. 11.

George, Jane. 2013. "Mining in Nunavik Leaves Alienated Inuit Watching From The Sidelines." Nunatsiaq News, May 28.

Gouvernement du Québec. 1995. Certificat d'Autorisation. Projet Minier Raglan, N/Réf.: 3215-14-03, Sainte-Foy, Ministère de l'Environnement et de la Faune.

Green, Heather. 2013. "State, Company, and Community Relations at the Polaris Mine (Nunavut)." Études/Inuit/Studies 37 (2): 37-58.

Guedel, W. Gregory. 2014. “Sovereignty, Economic Development, and Human Security in Native American Nations." American Indian Law Journal 3 (1): 17-39. 
Haley, Sharman, Matthew Klick, Nick Szymoniak, and Andrew Crow. 2011. "Observing Trends and Assessing Data for Arctic Mining." Polar Geography 34 (1-2): 37-61.

Hobart, Charles W. 1979. Socioeconomic Impacts of the Nanisivik Mine on North Baffin Region Communities. Yellowknife, Government of the Northwest Territories, Baffin Region Inuit Association.

Humphrey, David. 2002. "From Economic to Sustainable Development: Establishing a New Framework for Mineral Extraction." Minerals and Energy - Raw Materials Report 17 (4): 3-9.

Ittinuar, Peter Freuchen. 2008. Teach an Eskimo How to Read ... Conversations with Peter Freuchen Ittinuar, edited by Thierry Rodon. Iqaluit: Nunavut Arctic College, Life Stories of Northern Leaders.

Jourdain, Marine. 2014. Création d'emplois et contribution des mines au développement de Kangiqsujuaq, Nunavik: un développement local Nickel? Mémoire de Master 2 - Économie du Développement Durable et de l’Environnement, AgroParis Tech et Centre d'écologie fonctionnelle et évolutive de Montpellier.

Kativik Regional Administration. 2007. Cadre Socioéconomique. Kuujjuaq: Service des ressources renouvelables, de l'environnement et de l'aménagement du territoire.

Keeling, Arn, and John Sandlos. 2009. “Environmental Justice Goes Underground? Historical Notes from Canada's Northern Mining Frontier." Environmental Justice 2 (3): 117-125.

Keller, Julien. 2012. Les impacts socio-économiques de l'exploitation minière sur les communautés autochtones de l'Arctique. Québec: Ministère des Ressources naturelles et de la Faune du Québec et Géologie Québec.

Knotsch, Cathleen, Peter Siebenmorgen, and Ben Brashaw. 2010. “Les 'ententes sur les répercussions et les avantages' et le bien-être des communautés: des occasions ratées?" Recherches amérindiennes au Québec 40(3): 59-68.

Knotsch, Cathleen, Ben Bradshaw, Maatalii Okalik, and Kelsey Peterson. 2011. Research and Information Needs Concerning Community Health Impacts and Benefits from Mining - A 2010 Community Visit Report. Inuit Tuttarvingat of the National Aboriginal Health Organization.

Kulchyski, P. and W. Bernauer. 2014. "Modern Treaties, Extraction, and Imperialism in Canada's Indigenous North: Two Case Studies" Studies in Political Economy 93: 3-23.

Labrador West Status of Women Council and Femmes Francophones de l'Ouest du Labrador. 2004. Effects of Mining on Women's Health in Labrador West. Labrador City: Labrador West Status of Women Council et Femmes francophones de l'ouest du Labrador.

Lanari, Robert, Simon Smith, and Paul Okituk. 1999a. A Report to the Community of Salluit. Kuujjuaq: Makivik Corporation.

Lanari, Robert, Simon Smith, and Paul Okituk. 1999b. A Report to the Community of Kangiqsujuaq. Kuujjuaq: Makivik Corporation. 
Lanari, Robert, Simon Smith, and Paul Okituk. 2000a. A Report to the Community of Puvirnituq. Kuujjuaq: Makivik Corporation.

Lanari, Robert, Simon Smith, and Paul Okituk. 2000b. A Report to the Community of Quaqtaq. Kuujjuaq: Makivik Corporation.

Lanari, Robert, Simon Smith, and Paul Okituk. 2000c. A Report to the Community of Kangirsuk. Kuujjuaq: Makivik Corporation.

Laneuville, Pascale. 2013. Chasse et exploitation minière au Nunavut : une expérience inuit du territoire à Qamani'tuaq (Baker Lake), Master's thesis, Université Laval, Québec.

Lesage, Jean. 1955. "Enter the European. V - Among the Eskimos (Part II)." The Beaver 285: 3-9.

Lim, Tee Wern. 2013. Inuit Encounters with Colonial Capital: Nanisivik - Canada's First High Arctic Mine, Master's thesis, University of British Columbia, Vancouver.

McPherson, Robert. 2003. New Owners in Their Own Land. Minerals and Inuit Land Claims. Calgary: Calgary University Press.

Midgley, Scott. 2012. Co-producing Ores, Science and States: High Arctic Mining at Svalbard (Norway) and Nanisivik (Canada). Master's thesis, Memorial University of Newfoundland, St. John's.

O’Reilly, Kevin and Erin Eacott. 1999/2000. “Aboriginal Peoples and Impact and Benefit Agreement: Summary of the Report of a National Workshop." Northern Perspectives 25 (4): 4-15. http://www.carc.org/pubs/v25no4/2.htm.

Page, Robert. 1986. Northern Development. The Canadian Dilemma. Toronto, McClelland and Stewart.

Peterson, Kelsey. 2012. Community Experiences of Mining in Baker Lake, Nunavut. Master's thesis, University of Guelph, Guelph.

Prno, Jason and Scott S. Slocombe. 2012. "Exploring the Origins of 'Social License to Operate' in the Mining Sector: Perspectives from Governance and Sustainability Theories." Resources Policy 37(2): 346-357.

Rideout, Denise. 2002. "Arctic Bey Residents Want to Save Nanisivik Site." Nunatisaqonline, www.nunatsiaqonline.ca/archives/nunavut020118/news/ nunavut/20118_2.html.

Robertson, Gordon. 1960. "Administration for Development in Northern Canada: The Growth and Evolution of Government." Canadian Public Administration 3(4): 354-362.

Rodon, Thierry. 2010. “La construction des politiques du Nunavik et d’Eeyou Istchee: les défis du fédéralisme autochtone." In Les Cris et les Inuit du Québec edited by J. Petit, Y. Bonnier Viger, P. Aatami, and A. Iserhoff, 133-148. Québec: Presses de l'Université du Québec, Rennes, Presses de l'Université de Rennes.

Rodon, Thierry, Francis Lévesque, and Jonathan Blais. 2013. "De Rankin Inlet à Raglan, le développement minier et les communautés inuit. "Études/Inuit/Studies 37(2): 103-122. 
Rodon, Thierry, and Francis Lévesque. 2014. "Gap Analysis: Mining Development in Canada. ReSDA Gap Analysis Report \#2b." Whitehorse: Yukon Research Centre, http://yukonresearch.yukoncollege.yk.ca/resda/wp-content/uploads/ sites/2/2014/09/Rodon-Final-Gap-Report.pdf.

Rodon, Thierry, Francis Lévesque, and Sheena Kennedy-Dalseg. In Press 2015. "Improving Access to University Education in the Canadian Arctic. Learning from Past Experiences and Listening to Inuit Students' Experience." McGill Journal of Education.

Rodon, Thierry, Mylène Riva, and Jonathan Blais. 2014. Resource Revenue Distribution and Community Development and Well-Being: Evidence from Salluit and Kangiqsujuaq. ICASS VIII, Prince George, 25 May 2014.

Sachs, Jeffrey D., and Andrew M. Warner. 2001. "The Curse of Natural Resources." European Economic Review 45: 827-838.

Sandlos, John, and Arn Keeling. 2012. "Claiming the New North: Mining and Colonialism at the Pine Point Mine, Northwest Territories, Canada." Environment and History 18(1): 5-34.

Socio-economic Monitoring Committee. 2011. Annual Report of the Kivalliq Socioeconomic Monitoring Committee.

Socio-economic Monitoring Committee. 2012. Annual Report of the Kivalliq Socioeconomic Monitoring Committee.

Simard, Manon. 2004. "Literature Review of Arctic Char (Salvenius Alpinus) in Deception Bay and Aurrounding Tributaries." Kuujjuaq: Nunavik Research Center, Report 12-2004-1.

Tester, Frank, and Peter Kulchyski. 1994. Tammarniit (Mistakes). Inuit Relocations in the Eastern Arctic, 1939-1963. Vancouver: UBC Press.

Tester, Frank J., Drummond, E.J. Lambert, and Tee Wern Lim. 2013. “Wistful Thinking: Making Inuit Labour and the Nanisivik Mine Near Ikpiarjuk (Arctic Bay), Northern Baffin Island." Études/Inuit/Studies 37(2): 15-36.

White, Graham. 2009. "Nunavut and the Inuvialuit Settlement Region: Differing Models of Northern Governance." In Northern Exposure: Peoples, Powers and Prospects in Canada's North edited by F. Abele, T. Courchene, F. St. Hilaire, and L. Seidle, 283-316. Montréal: Institute for Research on Public Policy.

Williamson, Robert G. 1974. Eskimo Underground. Socio-Cultural Change in the Canadian Central Arctic. Uppsala: Institutionen för Allmän Och Jämförande etnografi vid Uppsala Universitet.

Zaslow, Morris. 1988. The Northward Expansion of Canada 1914-1967. Toronto, McClelland and Stewart. 